No. 3(60), 2019, pp. 9-21

https://doi.org/10.12797/Politeja.16.2019.60.01

\author{
José Luis BELLÓN AGUILERA (D) \\ Masaryk University \\ 116683@mail.muni.cz
}

\title{
A PNYX OF RESEARCH FIELDS
}

\section{MULTIDISCIPLINARITY ABOUT SORTITION AND DEMOCRACY ${ }^{1}$}

ABSTRACT This article conveys the objectives and results of an international and multidisciplinary - or interdisciplinary - research project still in operation, until the end of 2018. Based in the University of Cádiz (Spain), this project deals with ancient, modern and contemporary discussions, representations and narratives of Democracy, focusing on the contrast and comparison between a democratic system based on sortition, namely - broadly speaking - selection by lot to public offices and representative democracy. The article discusses the relevance of the investigation, the applicability of the results and the real effects of the actionresearch part. It also argues that - paradoxically - scientific autonomy is indispensable if that kind of research seeks to achieve tangible impact in society and its political fields. In short, this article asks about the inevitable fragility of the interaction between ethics, political commitment, and investigative objectiveness in humanities and social sciences.

Key words: multidisciplinarity, research, sortition, democracy

\footnotetext{
This article is a revised version of the paper "Philosophy, History, Sociology, Archaeology, Philology. About Democracy", presented at the Uniwersytet Pedagogiczny in Kraków, in the conference Philologies and the Construction of an Open Society. Possibilities, Goals, Challenges (20-21 October 2017). I would like to thank Jorge Costa and F. Manuel Carballo for reading it and for the suggestions that they made in reference to the draft. Another - much shorter - text was read on the 26 May 2018 at the 2018 Hic Rosa Studio in Politics \& Aesthetics: Re/In/Citing Politics After Capital and Colony, 2526 May 2018, in Brno, Czech Republic. This text has been written as part of the $\mathrm{R}+\mathrm{D}$ research project 'Reception of Greco-Roman Philosophy by French and Spanish Philosophy and Human Sciences from the 1980s to the Present' no. FFI2014-53792-R (2015-2018).
} 
A revival of direct democracy or a rejection of direct democracy based on new arguments points forward to the next millenium. As the world is today, there is obviously and opposition between modern democracy, which is indirect and centered in elections, and ancient demokratia, which was direct rule by the people in assembly.

(M.H. Hansen, Was Athens a Democracy? Popular Rule, Liberty and Equality in Ancient and Modern Political Thought, Copenhagen 1989, p. 6)

Have I done something for the common good? Then I too have benefited. Have this thought always ready to hand: and no stopping.

(Marcus Aurelius, Meditations, XI, 4; transl. by M. Hammond, 2006)

\section{INTRODUCTION}

Before coming to the conference at the University of Krakow, I thought about choosing another title for this presentation, something like: 'Humanities and Social Sciences in Times of Crisis'. With the thorny word "crisis", overloaded with emotional as well as vague socio-economic connotations, I was alluding not only to the crisis of the Humanities in general, but also to the crisis of representative democracy - not only European but at a global level. The first problem has been under discussion for long and the Krakow conference, where the opportunity was given to present our project, was addressing it. All presentations - and the following debates - were very enriching and inspiring, fitting altogether around the notion of a Not for Profit "Liberal arts" sort of education. ${ }^{2}$ In relation to that notion is the second problem - the global legitimacy crisis of democratic regimes - the subject in fact of the research project I am about to describe and briefly discuss in this short article: the role of Humanities and Social Sciences in a world of post-factual - or post-truth - politics. The aim of this paper is to claim that a philosophical-literary curriculum have not only an obvious educational and desirably human abstract goal - namely, create free judicious enlightened democratic citizens. Education, broadly speaking, as well as research in Humanities and Social Sciences can also play a decisive role to change the reality in which we live our day-to-day social lives. One the main legacies of the Ancient Greece is that democracy and philosophy are closely linked; for Cornelius Castoriadis and Jacques Rancière, for example, democracy is philosophy in practice. ${ }^{3}$ This paper is written in that spirit.

\footnotetext{
See M. Nussbaum, Not for Profit. Why Democracy Needs the Humanities, Princeton 2010.

3 J. Rancière, Hatred of Democracy, transl. by S. Corcoran, London 2006 and idem, Disagreement. Politics and Philosophy, Minneapolis 1999 (1 $1^{\text {st }}$ ed.: La Mésentente. Politique et philosophie, Paris 1995); C. Castoriadis, Ce qui fait la Grèce, vol. 2: La cité et les lois. Séminaires 1983-1984 (La création humaine, 3), Paris 2008 .
} 


\section{A SPECIAL CONTEXT: A CONTEMPORARY CRISIS OF REPRESENTATIVE DEMOCRACY}

Ours are difficult times. There is an undisputed, 'widespread and growing perception that contemporary democracy, especially perhaps in those countries where something reasonably called democracy has been in existence the longest, is being diminished, managed, or hollowed out. ${ }^{\prime}$ Many citizens - globally - have lost faith in their political representatives. It is not so much a disbelief in the political system as such, as it exists now - more or less imperfectly - in many countries with a long established tradition of liberal parliamentary democracies, but a feeling of disenchantment. Globally, politicians and citizens alike, regardless of their ideologies, express this sense of moral exhaustion. This is discernible in the distrust or scepticism, sometimes even emotional cynicism, of many millions of people towards other few people at the top of traditional political parties: leaders, political managers, professionals of politics. It is a disbelief which lies behind some several civic rebellions and social movements which have sprung recently, triggered also by the economic crisis of 2008 provoked by the excesses of financial banking in Wall Street - a crisis comparable to the Stock Market Crash of 1929. Those citizens' revolts and social movements were inspired by the Spanish 'Indignados' (engl. 'Indignant', 'angry') of the Movimiento 15- $M$, initiated in May (thus the 'M') 2011. The 15M had effects internationally, as seen in the New York protest movement Occupy Wall Street (OWS) from September 17, 2011, and the French social movement Nuit debout that began few years later, on the $31^{\text {st }}$ March 2016. The Spanish 15-M - a deliberative assembly movement - is, in fact, a complex social phenomenon linked also to the aforementioned economic crisis of 2008, that deeply affected Spain from 2009-2010, leading to the budget mayor cuts of 2011 and imposed by the EU from Brussels. ${ }^{5}$ The Arab Spring (a name inspired by the Revolutions of 1848 - the "Springtime of Nations" - and the Prague Spring of 1968), a wave of demonstrations, protests and open social revolts that began in Tunisia in 2010 and spread to North Africa and the Middle East, though a complicated phenomenon, can be considered a precedent of the $15 \mathrm{M}$. Both were an impulse for real democratization and a revolt against governmental corruption, and technology played an important role in the spread and organization of those social movements.

Nevertheless, social movements such as the $15 \mathrm{M}$ or OWS are symptoms of something much deeper. The global crisis of belief in parliamentary democracy is leading to massive abstention, firstly, but also to a worryingly significant upsurge of the support to far-right politics and other extremist ideologies and groups - extreme nationalist, chauvinist, xenophobic, racist or reactionary. This can lead to that political monster, feared by Popper - to whom the conference in Krakow was devoted: Totalitarianism.

P. Cartledge, Democracy. A Life, Oxford 2016, Kindle edition, p. 5.

A recent sociological analysis of the 15-M can be read in A. Razquín Mangado, Didáctica ciudadana. La vida politica en las plazas. Etnografía del movimiento 15M, Granada 2017. 
I am aware of the apparently theatrical character of these words: 'A spectre is haunting Europe - the spectre of Fascism', and it may be exaggerated, though I personally am convinced that it is a real danger. The political gains made by the far right and the essentially anti-democratic spectrum since the 2010 s cannot be ignored.

Still, "far-right" or "radical-democrats" apart, it is an almost implicit obviousness that promises, programmes or words uttered by professional politicians in the media or elsewhere lack in credibility. What are the reasons for this? It can be summarized as follows: on the one hand, there are professional politicians who, at best, are only specialists in moving through the echelons within the logic of the political field - a system of political parties - being themselves disconnected from the real problems of the majority of the population. On the other, there are elected people working without the people and sometimes only for some people. Those - at worst - can be politicians and public figures involved in politics (lately entrepreneurs and businesspersons turned politicians) who only care about their careers and the money they make for themselves and the interests of various multinationals. There are, of course, some political figures acting in good faith, from a belief in liberal ideas and capitalist markets. There are numerous exceptions, of course, and nuances, but for many representatives today, politics is mainly about career opportunities - along the way, of course, for the Country and the Party - than anything else, if not a path to the loss of faith in democracy and the case of the corrupted ones.

\section{THE DARK SIDE OF REPRESENTATIVE DEMOCRACY}

The preceding paragraph contained too strong statements. I will try to expand the short summary in a more formalized way. The previous text mentioned two main causes leading to a general disappointment with "representative democracies": firstly, the gap existing between represented and representatives caused by disconnection between candidates and their voters, as well as by political careerism; secondly, excessive selfinterest and corruption. It also has been said that the economic crisis of 2008 triggered the streets movements also mentioned above. However, it was also argued that the factors leading to the civil movements were latent much before. In a way, corruption is a blot of almost all societies and political systems, obviously in different levels, and mechanisms can be created to control it. "Corruption" is not an argument, and people are not stupid: eventually, they know when their "representatives" are abusing their positions for their private advantage. A more nuanced explanation of this need to be developed. The second reason, the cut between politicians and their voters, it is more important for the argumentation of this article.

First, professionalization of politicians is an effect of representative democracies. The thesis originates in the classical essay by German economist and sociologist Max Weber in his famous lecture 'Politics as a Vocation' ('Politik als Beruf', 1919). This is also linked with elites and with social conflict, but there is no space here to explain more about it. To sum up, there are people who live from politics. Nevertheless, to say 
that political elites have always existed and this tendency to professionalization is an effect of politics as such does not solve the problem, because institutional mechanisms may be created to avoid or at least to control the undesired consequences of that professionalization, namely, the urge to keep your job at all costs, even if that means to betray the vital interests of those you are supposed to represent in government.

Secondly, according to the sociologist Robert Michels (1876-1936) and his "iron law of oligarchy" theory, political systems have a tendency to create oligarchies, meaning that every political organization ultimately begets them. ${ }^{6}$ This is due to operational reasons, considering that those reasons are such because of the way the electoral and party system structures politics. But what Michels' theory implies is that the struggle for power, the ambition to be "the first" or among "the best" - the competition game is intrinsic to the political field. This leads to the concentration of power in a few hands, in leaders, their entourages and cliques, in a sort of patronage-effect. All that means that "representative democracies" are in fact "representative oligarchies": People are free once every four years to elect representatives who are unaccountable as from time to time they tend to forget about their promises because of the political game and its demands and challenges ("nothing personal, just politics"). Manin (1995), Dowlen (2008) Sintomer (2011) and others, better develop the arguments presented here in a way perhaps too crude. History shows that there are methods to control corruption and "oligarchisation". It has existed and it can inspire the creation of institutional devices to regulate or even to eradicate it. The strongest historical example mixing sortition, short term service rotation and accountability to avoid political professionalization is Athenian Democracy. ${ }^{7}$ It is interesting to note, incidentally, that Hansen pointed that out already in 1989 - see the quote heading this article. ${ }^{8}$

However, I would like to emphasize that the system of direct democracy is not endorsed here because the growth of extremism, but it is a proposal of improvement of the real existing representative democracies. It was also suggested above that massive abstention is also an effect of the political and systemic disenchantment with representative democracy. In reality, "representation" is - as has been briefly explained - a more or less open form of an oligarchic government, a government of few in which citizens are only free a few seconds every four years or so, to vote one candidate they have seen or heard in the mass media. Whatever may be said about that issue, in any case, contributions from research, like the one succinctly described in this article, help to deliberate about alternative representations of representative democracies, thus questioning the spontaneous theory of our political regimes, i.e., the spontaneous belief that there can be no other democracies or that current forms of democracies cannot be improved. It is not only possible to think of innovations that make the democratic procedures of

6 Michels theory was developed in a book in 1911: R. Michels, Political Parties. A Sociological Study of the Oligarchical Tendencies of Modern Democracy, Glencoe 1949, esp. Part Six, pp. 365-408.

7 M.H. Hansen, The Athenian Democracy in the Age of Demosthenes. Structure, Principles, and Ideology, Norman 1999.

8 Idem, Was Athens a Democracy? Popular Rule, Liberty and Equality in Ancient and Modern Political Thought, Copenhagen 1989, p. 6. 
our institutions better - more inclusive, more pluralist - but it is also desirable to think about political organizations more open to the political participation of a large number of citizens. 'Many forms of Government have been tried, and will be tried in this world of sin and woe. No one pretends that democracy is perfect or all-wise. Indeed it has been said that democracy is the worst form of Government except for all those other forms that have been tried from time to time.' That verdict was attributed to Churchill, who had in mind a democracy of representatives elected by a census of citizens, once every two, three or four years, in strict secrecy and liberty of decision. That model of democracy could be changed to a different kind of democratic political system in which there is a real and direct involvement of citizens in their functioning. Or, at least, it could be implemented with a more participative system based on sortition, filling the gap between those who govern and the citizens who are governed, because this gap is too large and that this gap helps neither the citizens nor the health of the political systems where it is found?'

To conclude this section, the context in which our research is being produced is one of dark times. We are going through profound transformations, not knowing indeed where we are heading. Still, in transitional times anything can happen, absolutely anything, including positive changes. Transitions, as historians know, are open to many possibilities.

\section{CONFRONTING CRISIS WITH (IM-)PURE RESEARCH}

One of the objectives of our research project is precisely confronting that crisis of belief in democratic systems, but keeping at the same time scientific autonomy. It is a research project, focused on a study of ancient and modern democracies, setting out from a belief that 'the current global preoccupation with democracy and (for some) its global extension makes constant re-examination of the original ancient Greek versions imperative. ${ }^{10}$ We interrogate the diagnosis of the crisis of representation in the wake of ground-breaking work by Bernard Manin, The Principles of Representative Government. ${ }^{11}$ The names of philosophers Cornelius Castoriadis, Jacques Rancière or Antoni Domènech are also associated with the philosophical foundations of the research. ${ }^{12}$

9 O. Dowlen, J. Costa Delgado, El sorteo en política. Cómo pensarlo y cómo ponerlo en práctica, transl. by J.L. Bellón Aguilera, Sevilla 2016, p. 1.

10 P. Cartledge, Democracy..., loc. 129.

11 B. Manin, Principes du gouvernement représentatif, Paris 1995 (English translation: The Principles of Representative Government, Cambridge 1996). Bibliography is very extensive, see for example:

O. Dowlen, The Political Potential of Sortition. A Study of the Random Selection of Citizens for Public Office (Sortition and Public Policy), Exeter 2008; Y. Sintomer, Petite histoire de l'expérimentation démocratique. Tirage au sort et politique d'Athènes à nos jours, Paris 2011. Sintomer is part of our research group. For the collaboration of Dowlen, see below.

12 My intention in this paper is not to engage in a description of these works, but to focus on its subject matter. It was the cited work of B. Manin, nonetheless, that sparked the debate around the crisis of contemporary democracies. 
In all kinds of academic investigation, there is a scientific dimension, a philosophical dimension, but there is also the goal of making something out of that research, out of all the discussion, debates and publications. "Pure" research does not exist, for there is at the end an "impure" - or "mundane" - aspect in its educational disclosure and popularization. Humanities and Social Sciences include a complex ethics of socialization of distribution of knowledge. Even if the researcher must assume a gap between her/his specialized knowledge and the simplification implicit in popularized information, it is assumed that you do not study for study's sake. You do research because your ultimate goal is to make better - flourish - the life of others who are paying you so that you can have the time and resources to, let us say, investigate the interweaving of love and politics in Plato's Symposium or Republic. Denying it would be pure cynicism or plain stupidity. Too much candour leads to naivety, but the opposite is a form of closed mind. ${ }^{13}$

On the other hand, not all kinds of research are susceptible to social transference. I am not implying that there is a kind of hierarchy between those different dimensions involved in any research in humanities: scientific, ethical or political, etc. There are undoubtedly many fascinating themes and areas in the history of humankind to study. This should be absolutely clear: all possible research is interesting, and it may be that one day - who knows - a pure in depth philological study of, for example, the prosody and metrics of some late Roman poet, or, the cuisine in the III Reich and the literary style of its recipe books, may reveal something useful for the community. However, in times of crisis there are priorities, one of them being that something from research must be transferred to society.

The social and humanities researcher must be autonomous in its creative process. The more autonomous the creative process, the more effective the results will be. This also applies to political philosophy. In Ancient Athens, democracy was discussed and theorised in tragedies, and philosophical enquiry, out of the political system, could lead to conflict, of which the exile of Protagoras or the death of Socrates are sufficient proof.

Scientific autonomy from economic or political goals ensures the quality of the work produced, and therefore its effects. However, there must exist a kind of commitment, or "engagement" with democratic values and with universal truth, devoting research to improve any particular area of society: ethics, politics, gender equality, ethnicity, critical thinking, etc., be that through education, writing or with interactions with the literary and artistic fields. In that aspect, the role of different areas covered in the past by "philosophy" - political science, sociology, theory or historiography - is central. Specialization is unavoidable for creative autonomy and excellence, but the opposite can be said for social transference of results, though socialization is a more than a desirable outcome. In any case, it is not the role researchers to disclose and distribute knowledge. Not at least in the first instance. Heteronomous researchers and popularisers - intelligent as may be - dwell in the fringes of the field of science, between the

13 Another issue are the economic interests of companies and enterprises in academic research - a too broad topic to cover in this article, that is, by the way, focused on humanities. 
literary and the specialized field. Here, we could speak about the indispensable collective character of production and distribution of knowledge.

A word may be added in relation to the "commitment" of academic research. It may sound naïve, but personally, I finally ended up very tired of postmodern cynics and cultural relativists who do not believe in anything and do nothing except morally condemn or just despise a system, our system, which is undoubtedly hard, unjust and very imperfect, but one that can be changed. You have to start somewhere, because - as written by Epicurean Roman poet Titus Lucretius Carus in his poem De rerum natura - On the Nature of Things - 'nullam rem e nihilo gigni divinitus umquam' (I, 150), 'nothing from nothing can ever be borne by divine action. It may also be that your work will change nothing, but it can at least contain or improve something. All economic and political systems in history were built on the overwork of the many, and there are very dark forces in some forms of extreme capitalism that need to be contained. No one will question the unquestionable: truth has its own force. However, it could even be that, in the end, not much could be done to avert its possible collapse, for the possible environmental destruction of the planet is a reality. We cannot be sure about it now. In that respect, one better be a pessimist because of intelligence, but an optimist because of will... or chose another job.

That having been said, our article turns to a general description of the project and its outcomes.

\section{A RESEARCH PROJECT FOR OTHER DEMOCRACY}

The title of the project reads: 'The Reception of the Greco-Roman Philosophy in Spain and France from 1980 to the Present Day. ${ }^{14}$ The Spanish Ministry of Education funds it, its base is in the University of Cádiz and its coordinator and one of the main researchers is the philosopher and sociologist José Luis Moreno Pestaña, who was the first person to inspire and drive the research.

The research combines sociology of the reception (a reader-response criticism or reception theory) of ancient political philosophy with an analysis of its meaning and appropriations today, as well as a reflection on his possibilities of applications. It includes, among the activities of knowledge-transference to society, the realization of a guide about the use of sortition (see below). Sortition - lottery-appointment of public offices in politics - was one of the main distinctive traits, if not the key, of Athenian democracy, and survived in some other ancient and medieval republics. The recuperation is still under debate from philosophical, historical and sociological points of view, but there have been few experiments put into practice. At this point, it would be more useful to be more specific.

As was described in the title of this presentation, it is a multidisciplinary and international team of researchers: among them there are sociologists, philosophers,

14 Proyecto de I+D: 'La recepción de la filosofía grecorromana en la filosofía y las ciencias humanas en Francia y España desde 1980 hasta la actualidad’ FFI2014-53792-R (2015-2018). 
political scientists, philologists, communication scientists, a historian of art and one independent researcher. ${ }^{15}$ There are probably some differences between "Multidisciplinarity", "Interdisciplinarity" and "Transdisciplinarity", but these are shades and nuances to delineate what - in my opinion - could be described as a group of researchers who share information and specialized research as part of a network - a "Pnyx" of fields - created by the project. ${ }^{16}$ But considering that they share knowledge from different disciplines but remaining within their boundaries, the character of their interaction is more "multidisciplinary" than interactive, not as if analyzing the same object from different angles, but studying different aspects of it - historical, sociological, philosophical, etc. - and integrating ideas and results from others in their respective theoretical approaches and problematics. Two examples will suffice: the sociological work about the Spanish "Asambleas" in the "plazas" (squares) - the aforementioned " $15 \mathrm{M}$ " - can be integrated in a more theoretical work by political scientists or philosophers. In addition, the historiography of the appropriations of Athenian democracy in the past can be incorporated to study the ideological misconceptions around "other" forms of democracy than the representative, namely the direct democracy and the mechanisms of sortition.

The general objectives of the research are the following: first, to elaborate a sociological reconstruction of the reception of ancient political philosophy in Spain and France from the 1970s to the present day. Secondly, to investigate the possibilities that are offered by the actualization and reintroduction of arguments of ancient political philosophy for the political practice in the present time. Thirdly, it is the creation of a tool-work that enables to know and put into practice the use of sortition in contemporary political Iistitutions and organizations. ${ }^{17}$

15 Sociologists: Adriana Razquín (Universidad de Jaén), Stanislas Morel (CNRS), Gerard Mauger (CESSP-CNRS). Philosophers and politologists: José Luis Moreno Pestaña, Francisco Vázquez García, Francisco M. Carballo Rodríguez, Jorge Costa Delgado (Universidad de Cádiz), Yves Sintomer (politologist, Institut Universitaire de France), Arnault Skornicki (Institut des Sciences Sociales du Politique, Université Paris Ouest, Nanterre-La Défense). Communication sciences: Francisco J. Moreno Gálvez (CIESPAL - Centro Internacional de Estudios Superiores de Comunicación para América Latina, now in Universidad Carlos III de Madrid and in the Fundación por la Europa de los Ciudadanos). Philologists: Liliane López-Rabatel (Institut de recherche pour l'architecture antique - CNRS-Lyon 2 - part of her research about the machines for sortition, the kleroteria, is also in relation with Archaeology), José Luis Bellón Aguilera (Hispanic Studies, Classics, Masarykova Univerzita). Philosophy and History of Art: Juan José Gómez Gutiérrez, also editor in the Colectivo Efialtes, created along with the project (now in Universidad del País Vasco). There was also a partial involvement of Oliver Dowlen (independent researcher, Research Group on Democratic Procedures - PROCEDEM, Sciences Po). Among invited specialists to conferences by the project was Laura Sancho Rocher, prof. of Ancient Greek History at University of Zaragoza; Fernando Aguiar, Faculty Member of the CSIC (Spanish National Research Council), and IESA (Institute for Advanced Social Studies); Philippe Urfalino, Directeur d'études EHESS and Directeur de recherche CNRS.

16 The Pnyx is a hill in Athens on which the citizens Assembly held most of its meetings in the classical period. It lay about $400 \mathrm{~m}$ south-west of the Agora (M.H. Hansen, The Athenian Democracy..., p. 401).

17 See a "Una breve presentación de nuestro I+D" (A brief presentation of our I+D), Efialtes. Un blog sobre las lecturas contemporáneas de la democracia ateniense, 16 August 2015, at <http://sociologyofphilosophy.blogspot.cz/2015/08/una-breve-presentacion-de-nuestro-id.html>. 
The specific objectives are five: first, to analyse the complex relation between experts and politics in a democratic context, focusing particularly on the role played by the division of work in the political sphere that discredit sortition as a political practice. The platonic debate between Socrates and Protagoras and the influence of the development of scientific thought over the political field in Modernity are two important landmarks in the history of this process. In that respect, it is seen as necessary to improve the history of the use of sortition, to spot unknown or forgotten cases, and to track its withdrawal from those institutions and contexts in which it was used. This will allow gaining a wider and better informed perspective to study the possible causes of that removal or disappearance.

Secondly, the research seeks to create a map of the different readings of ancient Philosophy in France and in Spain in the particular period. The starting point will compare those readings of ancient philosophy established as canonical in both countries (for example, Fustel de Coulanges and Francisco Rodríguez Adrados) and the new interpretations of those philosophers whose interest in that area has revived in that temporal framework under study. A special part will be devoted to the analysis of the reception of the technologies of the self in Spanish and French philosophy, considering mainly their value for the construction of the democratic citizen. Thirdly - to draw a map similar to the above-mentioned for the readings of ancient philosophy in the field of social sciences in France and Spain.

Fourth, in the draft of 2015 there was a proposal of a collaborative action research: to study the value and functioning of those arguments recovered from ancient political philosophy in a particular political experience. A political group interested in cooperating in this experience was contacted but at the start it was not possible to specify the model of research because it depended not only on the local political situation (council elections in 2015), but also on the results of the first year of research. According to the schedule foreseen at the official announcement and for the project, it was proposed, therefore, that the action research would be carried out during 2016 or 2017. Due to these factors, there two options were suggested: (a) To carry out the collaborative action research through the cooperation with the City Council of the locality to which the interested political group mentioned belonged: identifying a social or political problem of the district and introducing dynamics of citizen participation for deliberation and management, as indicated in the next section. (b) To carry out the collaborative action research through the cooperation with the political group interested: identifying a key social or political problem for the group and introducing dynamics of citizen participation for deliberation and internal discussion and the devise of proposals on the part of the group (see below).

Fifth, the goal was preparing a guide about the problems and virtues of participative democracy in democratic institutions and the political practice of political organizations.

The governmental funding amounted only to 10.000 euros, and the first draft was rejected by the MEC, the Ministry of Education. However, due to the results, the project obtained an extension of one year, until the end of 2018. 


\section{OUTCOMES. PUBLICATIONS}

It is not possible to give a full account of the publications produced during these last 3 years. The two main successes were, first, the monograph about Sortition and Democracy in Daimon. Revista Internacional de Filosofia, coordinated by Jorge Costa Delgado, Liliane López-Rabatel, José Luis Moreno Pestaña and Yves Sintomer. ${ }^{18}$ Secondly, the monograph devoted to the reception of ancient democracy in Logos. Anales del Seminario de Metafisica. ${ }^{19}$ Both publications are in Spanish.

With the cooperation of Editorial Doble J, the Ephialtes Collective was created to support publications. J. L. Bellón Aguilera published a double translation into Spanish - one literal and another one commented and annotated - of one of the most controversial and fascinating texts dealing with ancient Athenian democracy: the ancient Greek pamphlet known as the Constitution of the Athenians. The text, mistakenly attributed to the Greek historian Xenophon, was written between 443 to as late as $406 \mathrm{BC}$ by an unknown author later nicknamed "Old Oligarch", and it is considered one of the first writings in the long anti-democratic tradition. The translation was preceded by an extensive study and an introduction..$^{20} \mathrm{~A}$ forthcoming publication is a text by sociologist P. Urfalino, translated from French into Spanish, by F. Manuel Carballo.

A blog named Ephialtes was created as part of the dissemination of information. ${ }^{21}$ It also contains a detailed description of the project, its members and its publications. The blog, written in Spanish, has been a crucial part of the spreading and circulation of research outcomes and a useful tool of communication between researchers. ${ }^{22} \mathrm{~A}$ guide in Spanish about sortition was also published - that has already mentioned: Sortition

18 Daimon. Revista Internacional de Filosofia, no. 72 (2017): Sorteo y democracia, at <http://revistas. um.es/daimon/issue/view/15861>, 24 January 2018. Also printed paperback edition.

19 Logos. Anales del Seminario de Metafísica, vol. 51 (2018): Monográfico: Recepciones de la democracia antigua, at <https://revistas.ucm.es/index.php/ASEM/issue/view/3378>, 24 January 2018.

20 J.L. Bellón Aguilera, Anónimo o "Viejo Oligarca": El sistema político de los atenienses. Estudio introductorio. Cronología. Glosario. Dos traducciones: literaria y literal-comentada, Sevilla 2017, 136 pp. See details at <https://editorialdoblej.com/2017/02/28/el-sistema-politico-de-los-atenienses-2/>, 24 January 2018 .

21 As it is known, Ephialtes was an Athenian politician from $5^{\text {th }}$ Century B.C.E (Before Common Era) Athens. He was a democratic revolutionary leader who, along with Pericles, drove or promoted the reforms that ended the power of the oligarchs and drove Athenian "radical democracy" to power, and later was assassinated (there is a malignant rumour saying that Pericles was involved in the crime).

22 Efialtes. Un blog sobre las lecturas contemporáneas de la democracia ateniense (Ephialtes. A Blog about Contemporary Readings of Athenian Democracy), at <http://sociologyofphilosophy.blogspot. $\mathrm{cz} />$, 24 January 2018. The project and their activities, publications, as well as its members, are fully described in the blog - in Spanish. The blog, who had another name before, has had so far approximately 120.000 visits, from August 2015. First entry of the one explained here dates from 16 August 2015, A Discussion of Sortition, at <http://sociologyofphilosophy.blogspot.cz/2015/08/una-discusion-sobre-el-sorteo-en-un.html>, 24 January 2018. 
in Politics. Thinking it an Putting into Practice [El sorteo en politica. Cómo pensarlo y cómo ponerlo en práctica]. ${ }^{23}$

\section{Collaborative Action-Research}

In 2014, the idea of the research project on Sortition and Democracy came about, while preparing a proposal for its application in Vistalegre I, the conference of the Spanish political party Podemos. It was called 'Deepening Democracy' [Profundización democrática]. From this contact a proposal was developed to study sortition in practice. Jorge Costa Delgado made a study in Cádiz and later wrote the guide already cited. ${ }^{24}$

\section{BIBLIOGRAPHY}

Bellón Aguilera J.L., Anónimo o "Viejo Oligarca": El sistema politico de los atenienses. Estudio introductorio. Cronología. Glosario. Dos traducciones: literaria y literal-comentada, Sevilla 2017, at <https://editorialdoblej.com/2017/02/28/el-sistema-politico-de-los-atenienses-2/>.

Cartledge P., Democracy. A Life, Oxford 2016, Kindle edition.

Castoriadis C., Ce qui fait la Grèce, vol. 2: La cité et les lois. Séminaires 1983-1984 (La création humaine, 3), Paris 2008.

Costa Delgado J., "Resistencias a la introducción del sorteo entre el asamblearismo y la institucionalización: el caso de Podemos en Cádiz", Daimon Revista Internacional de Filosofia, no. 72 (2017): Sorteo y democracia, https://doi.org/10.6018/daimon/293951.

Daimon. Revista Internacional de Filosofia, no. 72 (2017): Sorteo y democracia, at <http://revistas.um.es/daimon/issue/view/15861>.

Dowlen O., The Political Potential of Sortition. A Study of the Random Selection of Citizens for Public Office (Sortition and Public Policy), Exeter 2008.

Dowlen O., Costa Delgado J., El sorteo en politica. Cómo pensarlo y cómo ponerlo en práctica, transl. by J.L. Bellón Aguilera, Sevilla 2016, at <https://editorialdoblej.com/2016/10/02/ el-sorteo-en-politica-como-pensarlo-y-como-ponerlo-en-practica/> .

Hansen M.H., The Athenian Democracy in the Age of Demosthenes. Structure, Principles, and Ideology, Norman 1999.

23 J.L. Bellón Aguilera translated into Spanish one unpublished text by O. Dowlen 'The Political Potential of Sortition. A Study of the Random Selection of Citizens for Public Office' (2008), to which was added a text written by J. Costa: a guide to practically implementing sortition on a locality: O. Dowlen, J. Costa Delgado, El sorteo en política... It can be downloaded free of charge in the editorial page of the Colectivo Efialtes (at <https://editorialdoblej.com/492-2/>, 24 January 2018), supported by Editorial Doble J, at <https://editorialdoblej.com/2016/10/02/el-sorteo-en-politica-como-pensarlo-y-como-ponerlo-en-practica/>, 24 January 2018.

24 See blog entry at <http://sociologyofphilosophy.blogspot.cz/2015/10/propuesta-para-implementar -procesos-de.html>, and the article by J. Costa about rejection of sortition: "Resistencias a la introducción del sorteo entre el asamblearismo y la institucionalización: el caso de Podemos en Cádiz”, Daimon Revista Internacional de Filosofía, no. 72 (2017): Sorteo y democracia. 
Hansen M.H., Was Athens a Democracy? Popular Rule, Liberty and Equality in Ancient and Modern Political Thought, Copenhagen 1989.

Logos. Anales del Seminario de Metafísica, vol. 51 (2018): Monográfico: Recepciones de la democracia antigua, at <https://revistas.ucm.es/index.php/ASEM/issue/view/3378>.

Manin B., Principes du gouvernement représentatif, Paris 1995 (English translation: The Principles of Representative Government, Cambridge 1996).

Michels R., Political Parties. A Sociological Study of the Oligarchical Tendencies of Modern Democracy, Glencoe 1949.

Nussbaum M., Not for Profit. Why Democracy Needs the Humanities, Princeton 2010.

Rancière J., Disagreement. Politics and Philosophy, Minneapolis 1999 ( $1^{\text {st }}$ ed.: La Mésentente. Politique et philosophie, Paris 1995).

Rancière J., Hatred of Democracy, transl. by S. Corcoran, London 2006.

Razquín Mangado A., Didáctica ciudadana. La vida politica en las plazas. Etnografía del movimiento 15M, Granada 2017.

Sintomer Y., Petite histoire de l'expérimentation démocratique. Tirage au sort et politique d'Athènes à nos jours, Paris 2011.

"Una breve presentación de nuestro I+D" (A brief presentation of our I+D), Efialtes. Un blog sobre las lecturas contemporáneas de la democracia ateniense, 16 August 2015, at <http:// sociologyofphilosophy.blogspot.cz/2015/08/una-breve-presentacion-de-nuestro-id.html>.

José Luis BELLÓN AGUILERA - Assistant Professor, Department of Romance Languages and Literatures, Masaryk University, Brno (Czech Republic). Field of study: theory, sociology and history of Spanish literatures; reception of Classical Greek and Roman literatures. List of publications at: https://www.muni.cz/en/ people/116683-jose-luis-bellon-aguilera/publications. 